STUDIA I PRACE WYDZIAŁU NAUK EKONOMICZNYCH I ZARZĄDZANIA nr 40, t. 1

\author{
Jolanta Lubomska-Kalisz
}

\title{
ZASTOSOWANIE TRADYCYJNYCH STRATEGII KONKURENCJI PRZEZ WSPÓŁCZESNE PRZEDSIĘBIORSTWA
}

\section{Streszczenie}

W artykule zostały wyjaśnione i porównane pojęcia: koncepcja konkurencyjności przedsiębiorstwa oraz strategia konkurencji przedsiębiorstwa. Podjęto próbę rozwiązania dylematu, kiedy zastosować każde z tych pojęć. Przeprowadzono także przegląd wybranych tradycyjnych strategii konkurencji przedsiębiorstwa. Określono możliwość ich zastosowania w nowych warunkach otoczenia konkurencyjnego.

Słowa kluczowe: koncepcje konkurencyjności, strategie konkurencji, przedsiębiorstwo, konkurencyjność przedsiębiorstw

\section{Wprowadzenie}

W literaturze poświęconej problematyce konkurencyjności przedsiębiorstw zamiennie stosuje się dwa określenia: koncepcje konkurencyjności przedsiębiorstw i strategie konkurencji przedsiębiorstw. Jest to jednak duża nieścisłość, gdyż pojęcia te mają odmienne znaczenie. Dlatego ważne jest wyjaśnienie tego problemu. W związku z tym celem niniejszego artykułu jest przybliżenie istoty obu pojęć i próba rozwiązania dylematu, kiedy stosować każde z tych pojęć, a także przeprowadzenie przeglądu wybranych tradycyjnych strategii konkurencji przedsiębiorstwa

\footnotetext{
Adres e-mail: j.lubomska-kalisz@wp.pl.
} 
i określenie możliwości ich zastosowania w nowych warunkach otoczenia konkurencyjnego.

\section{Porównanie pojęć koncepcja konkurencyjności przedsiębiorstwa i strategia konkurencji}

Koncepcja konkurencyjności przedsiębiorstwa to ogólny sposób radzenia sobie z konkurencją, to sposób osiągania i utrzymania konkurencyjności przedsiębiorstwa, który określa główne instrumenty i mechanizmy konkurowania w krótkim i długim okresie. Do podstawowych elementów koncepcji konkurencyjności przedsiębiorstwa zalicza się:

- struktury rynkowych czynników konkurencyjności,

- struktury i sposoby kształtowania konkurencyjnych zasobów i umiejętności,

- strategie działań konkurencyjnych, przez które rozumie się zespół działań mających na celu odpowiednie usytuowanie danego przedsiębiorstwa wobec konkurentów (konfrontacja, alianse, unikanie, ignorowanie konkurencji).

Rozwiniętą koncepcję konkurencyjności przedsiębiorstwa opracował pod koniec lat 70. i rozwinął w latach 80. XX wieku M.E. Porter, uznany za specjalistę światowej sławy w dziedzinie zarządzania strategicznego. Swoją koncepcję, która miała wpływ na rozwój teorii i praktyki konkurencji przedsiębiorstw i krajów, zaprezentował w trzech publikacjach²: Competitive Strategy (1980) poświęconej ogólnym i szczegółowym strategiom konkurencji oraz metodom analizy otoczenia konkurencyjnego, Competitive Advantage (1985) koncentrującej uwagę na źródłach przewagi konkurencyjnej przedsiębiorstw oraz Competitive Advantage of Nations (1990) poświęconej źródłom przewagi konkurencyjnej poszczególnych krajów.

Strategia konkurencji (konkurowania) powszechnie rozumiana jest jako sposób zachowania się przedsiębiorstwa wobec konkurentów. W swoich książkach M.E. Porter określa, że strategia konkurencji jest „kombinacją celów, do których

\footnotetext{
${ }^{1}$ Z. Pierścionek, Strategie konkurencji i rozwoju przedsiębiorstwa, Wydawnictwo Naukowe PWN, Warszawa 2007, s. 199.

2 Por. M.E. Porter, Competitive Strategy, The Free Press, New York 1980; M.E. Porter, Competitive Advantage, The Free Press, New York 1985; M.E. Porter, Competitive Advantage of Nations, The Free Press, New York 1990.
} 
firma zmierza, i środków (zasad postępowania), za pomocą których stara się do nich dojść”. Autor ten uznaje, że „strategia konkurencyjności zakłada poszukiwanie uprzywilejowanej pozycji konkurencyjnej w branży, czyli najważniejszym z punktu widzenia konkurencji obszarze. Strategia konkurencyjności ma umożliwić wypracowanie solidnej i korzystnej pozycji wobec tych sił, które decydują o charakterze konkurencji w danej branży"4.

Próbę syntetycznego ujęcia różnorodnych wątków prezentuje podejście, że strategia konkurencji to „długookresowa koncepcja działalności przedsiębiorstwa, polegająca na określonych działaniach wobec klientów, konkurentów i dostawców, wiążąca wewnętrzne zasoby i umiejętności z wyzwaniami płynącymi z otoczenia, budowana dla zapewnienia przewagi konkurencyjnej w branży oraz osiągnięcia głównych celów organizacji”’’

Porównanie pojęć koncepcja konkurencyjności przedsiębiorstwa i strategia konkurencji przedsiębiorstwa pozwala wyciągnąć wniosek, że nie są to synonimy. Koncepcja konkurencyjności jest pojęciem szerszym i zawiera w sobie pojęcie strategii konkurencji. Koncepcja konkurencyjności przedsiębiorstwa to ogólny sposób radzenia sobie z konkurencją, to sposób osiągania i utrzymania konkurencyjności przedsiębiorstwa. Natomiast strategia konkurencji jest jednym z elementów koncepcji konkurencyjności, to zestaw celów, które przedsiębiorstwo chce osiągnąć, i zestaw środków (zasad działania, narzędzi) niezbędnych do osiągnięcia tego celu.

\section{Zastosowanie tradycyjnych strategii konkurencji M.E. Portera}

Stworzenie i utrzymanie przewagi konkurencyjnej w dłuższym czasie, z czym wiąże się osiągnięcie przez przedsiębiorstwo ponadprzeciętnej efektywności

\footnotetext{
${ }^{3}$ M.E. Porter, Strategia konkurencji. Metody analizy, sektorów i konkurentów, MT Biznes, Warszawa 2006, s. 17.

${ }^{4}$ M.E. Porter, Przewaga konkurencyjna. Osiaganie i utrzymywanie lepszych wyników, Helion, Gliwice 2006, s. 27.

5 W.F. Gluck, L.R. Jauch, Business Policy and Strategic Management, ed. 4, McGraw-Hill, New York 1984; M.E. Porter, Przewaga konkurencyjna ...; M.E. Porter, Strategia konkurencji. Metody analizy..., s. 17, podano za: Strategie konkurencji w handlu detalicznym w warunkach globalizacji rynku, red. M. Sławińska, Wydawnictwo Akademii Ekonomicznej w Poznaniu, Poznań 2005, s. 50.
} 
działania, wymaga zastosowania odpowiedniej strategii 6 . Strategie konkurencji formułowane są na poziomie strategicznych jednostek organizacyjnych (SJO), inaczej biznesu. Strategie na tym poziomie pozwalają znaleźć odpowiedź na pytania, jaki jest najlepszy sposób konkurowania na danym rynku oraz jakimi metodami tworzyć przewagę konkurencyjną danej strategicznej jednostki organizacyjnej. Warto zauważyć, że przedsiębiorstwa rzadko stosują czyste strategie, z reguły przyjmują strategie mieszane, np. opierające się na przewadze w jakości produktu oraz systemie obsługi, a także na określonych kombinacjach strategii cenowych i jakościowych?

Według Z. Pierścionka, strategie konkurencji przedsiębiorstwa są to sposoby osiągania przewagi w wybranych obszarach, takich jak: jakość produktu, cena, jakość systemu obsługi, renoma firmy bądź w ich kombinacji. Uwzględniając powyższe parametry, autor ten wyróżnia następujące czyste strategie konkurencji: strategię najniższych cen, strategię opartą na jakości produktu, strategię opartą na jakości obsługi, strategię opartą na renomie firmy ${ }^{8}$.

M.E. Porter wyróżnia trzy podstawowe rodzaje wewnętrznie zgodnych strategii konkurencji (mogą być stosowane indywidualnie lub w kombinacjach), prowadzących do stworzenia i utrzymania pozycji przez długi okres i uzyskiwania lepszych wyników od wyników konkurentów w sektorze. Strategie te określane są w literaturze przedmiotu także jako strategie ogólne lub ofensywne9 ${ }^{9}$ Zalicza się do nich strategie ${ }^{10}$ :

- przywództwo kosztowe (wiodąca pozycja pod względem kosztów całkowitych),

${ }^{6}$ Uwarunkowania i sposoby wzrostu konkurencyjności przedsiębiorstw, red. M. Białasiewicz, Economicus, Szczecin 2009, s. 48.

7 Ibidem, s. 171.

${ }^{8}$ Z. Pierścionek, Strategie rozwoju firmy, Wydawnictwo Naukowe PWN, Warszawa 1997, s. 179.

${ }^{9}$ W literaturze przedmiotu trzy podstawowe strategie Portera stanowią podstawę wszelkich klasyfikacji strategii konkurencji. Do strategii Portera odnosi się wielu autorów, m.in.: Z. Pierścionek, Strategie konkurencji..., s. 265-269; B. Fryzeł, Kultura a konkurencyjność przedsiębiorstwa, Tonik, Toruń 2004, s. 70-72; M. Łuczak, Strategie w działalności przedsiębiorstwa, Wyższa Szkoła Ekonomiczna, Warszawa 2003; Przedsiębiorczość a strategie konkurencji, red. T. Tkaczyk, SGH, Warszawa 2000, s. 167-173; W. Szymański, Przedsiębiorstwo, rynek, konkurencja, SGH, Warszawa 1995, s. 229-233.

${ }_{10}$ Trzy podstawowe strategie M.E. Portera zostaną omówione głównie na podstawie M.E. Porter, Strategia konkurencji. Metody analizy..., s. 61-67. 
- zróżnicowanie (dyferencjacja),

- koncentracja.

Strategie przywództwa kosztowego i zróżnicowania mają na celu uzyskanie przewagi konkurencyjnej w szerokim zakresie rynku oraz przemysłu, natomiast strategia koncentracji - osiągnięcie przewagi kosztowej lub odróżnienie się w wąskim segmencie rynku ${ }^{11}$.

Strategia przywództwo kosztowe spopularyzowana w latach 70. XX w. polega na zdobyciu wiodącej pozycji w sektorze pod względem kosztów całkowitych. Podstawą całej strategii jest niższy koszt wytwarzania w porównaniu z konkurentami, bez obniżania jakości wytwarzanych produktów, poziomu obsługi. Osiągnięcie wiodącej pozycji kosztowej często wymaga wysokiego względnego udziału w rynku lub innego rodzaju przewagi, np. korzystnego dostępu do źródeł surowców ${ }^{12}$.

Drugą podstawową strategią konkurencji jest zróżnicowanie (dyferencjacja). Polega ona na zróżnicowaniu wyrobu lub usługi, na stworzeniu czegoś, co jest uznawane za unikalne. Zróżnicowanie może dotyczyć: wzoru wyrobu lub marki, technologii, cech wyrobu, obsługi posprzedażowej, sieci sprzedażowej itp. Z. Pierścionek określa tę strategię jako strategia dyferencjacji. Wyjaśnia, że polega ona na odróżnieniu się od rywali cechami ważnymi dla odbiorców. Strategia ta może opierać się na produkcie, systemie sprzedaży, systemie obsługi ${ }^{13}$. Osiągnięcie zróżnicowania pozwala uzyskać wyższą niż przeciętna stopę zysku w danym sektorze, ponieważ tworzy pozycję możliwą do obrony przed pięcioma siłami konkurencji ${ }^{14}$. Jednak najczęściej osiągnięcie zróżnicowania odbywa się za cenę gorszej pozycji kosztowej.

Trzecią podstawową strategią jest koncentracja, która może opierać się na określonej grupie nabywców, określonym wycinku asortymentu wyrobów lub na rynku geograficznym. Jest ona tworzona z myślą o szczególnie dobrej obsłudze danego segmentu. Efektem może być osiągnięcie przez firmę zróżnicowania dzięki lepszemu zaspokajaniu potrzeb swojego segmentu lub obniżeniu kosztów jego obsługi lub dzięki jednemu i drugiemu. Odmienność trzech podstawowych rodzajów strategii zaprezentowano na rysunku 1 .

${ }_{11}$ Z. Pierścionek, Strategie konkurencji..., s. 266.

12 M.E. Porter, Strategia konkurencji. Metody analizy..., s. 61-62.

${ }_{13}$ Z. Pierścionek, Strategie konkurencji..., s. 267.

${ }^{14}$ Pięć sił konkurencji M.E. Portera składa się z takich elementów, jak: konkurenci w sektorze, groźba wejścia nowych konkurentów, dostawcy, nabywcy, substytuty. 
Rysunek 1. Trzy podstawowe rodzaje wewnętrznie zgodnych strategii konkurencji według M.E. Portera

PRZEWAGA STRATEGICZNA

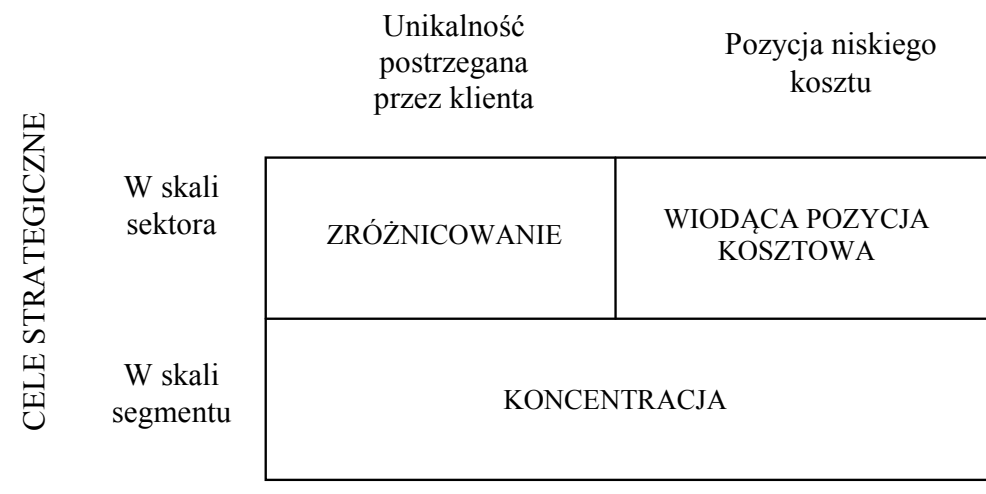

Źródło: opracowanie na podstawie M.E. Porter, Strategia konkurencji. Metody analizy..., s. 65.

Omówione powyżej trzy podstawowe rodzaje strategii konkurencji M.E. Portera różnią się względami funkcjonalnymi i nie tylko. Strategie te do skutecznego ich wdrożenia wymagają odmiennych zasobów i umiejętności, różnych rozwiązań organizacyjnych, procedur kontrolnych i systemów zachęt, stylów przywództwa. Mogą prowadzić do odmiennych kultur organizacyjnych i klimatu korporacji.

M.E. Porter określił dwie podstawowe zasady wyboru strategii konkurencji następująco ${ }^{15}$ :

- największe dostosowanie strategii do silnych stron firmy,

- największa trudność naśladowania strategii przez konkurentów.

Autor ten głosił, że dwie strategie, tj. przywództwo kosztowe i zróżnicowanie, mogą być wybrane alternatywnie, tzn. aby osiągnąć sukces, należy wybrać jedną $\mathrm{z}$ nich. W praktyce gospodarczej okazało się, że strategie te nie wykluczają się, a badania przeprowadzone w japońskich przedsiębiorstwach potwierdziły, że firmy te w sposób efektywny realizowały obie strategie jednocześnie. Wybór wśród trzech podstawowych strategii jest określony głównie przez wielkość firmy, dostęp do zasobów, charakter sektora i konkurencji. Duże firmy, funkcjonujące w przemysłach

${ }^{15}$ Z. Pierścionek, Strategie rozwoju..., s. 185. 
o wystarczającym dostępie do zasobów, konkurują głównie na bazie przywództwa kosztowego, a także zróżnicowania. Mniejsze firmy realizują przede wszystkim strategie koncentracji oraz zróżnicowania ${ }^{16}$.

\section{Zastosowanie rozbudowanego modelu tradycyjnych strategii konkurencji M.E. Portera}

W związku z powyższym zaproponowano rozbudowanie modelu M.E. Portera o dwie następujące strategie konkurencji ${ }^{17}$ :

- strategię wyczekiwania,

- strategię zintegrowaną.

Wzajemny układ strategii zaproponowanych przez M.E. Portera i uzupełnionych o strategię wyczekiwania i strategię zintegrowaną przedstawiono na rysunku 2.

Rysunek 2. Rozbudowany model strategii konkurencji M.E. Portera

\begin{tabular}{|c|c|c|}
\hline 芯 & $\begin{array}{c}\text { Strategia } \\
\text { zróżnicowania }\end{array}$ & $\begin{array}{c}\text { Strategia } \\
\text { zintegrowana }\end{array}$ \\
\hline 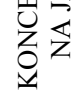 & $\begin{array}{c}\text { Strategia } \\
\text { wyczekiwania }\end{array}$ & $\begin{array}{c}\text { Strategia } \\
\text { przywództwa } \\
\text { kosztowego }\end{array}$ \\
\hline
\end{tabular}

KONCENTRACJA NA KOSZTACH

Źródło: opracowanie na podstawie W. Reitsperger, S. Daniel, S. Tallman, W. Chrsmar, Produkt Quality and Cost Leadership: Compatible Strategies?, „Management International Reviev” 1993, Special Issue No. 1, za: M. Romanowska, Strategie rozwoju i konkurencji, CIM, Warszawa 1998, s. 189.

16 P. Wright, A Refinement of Porter's Strategies, „Strategic Management Journal” 1987, Vol. 8, za: Z. Pierścionek, Strategie konkurencji..., s. 267.

${ }_{17}$ M. Romanowska, Zarzadzanie strategiczne firma, CIM, Warszawa 1995, s. 137, za: K. Janasz, W. Janasz, K. Kozioł, K. Szopik-Depczyńska, Zarządzanie strategiczne. Koncepcje. Metody. Strategie, Difin, Warszawa 2010, s. 100. 
Strategia wyczekiwania dotyczy podmiotów, które poszukują swojego miejsca w sektorze i racjonalnej strategii konkurencji. Polega ona na penetrowaniu sektora w poszukiwaniu szans rozwojowych i wzmacnianiu własnej pozycji. Zbyt długie realizowanie strategii wyczekiwania wiąże się z ryzykiem wypadnięcia przedsiębiorstwa z rynku. Strategia zintegrowana polega na jednoczesnym budowaniu obydwu rodzajów przewag konkurencyjnych, tj. wysokiej jakości i niskiego kosztu. Jest to trudne, gdyż wymaga konieczności ponoszenia nakładów kapitałowych na różne dziedziny funkcjonowania firmy.

Opracowując strategię konkurencji, przedsiębiorstwo powinno uwzględniać także rodzaj sektora, w którym funkcjonuje. M.E. Porter podkreśla konieczność uwzględnienia relacji pomiędzy specyfiką sektora działalności przedsiębiorstwa a wariantami strategii konkurencji. Na tej podstawie wyróżnia on strategie konkurowania w sektorach: rozproszonych, pojawiających się, dojrzałych, schyłkowych i globalnych ${ }^{18}$.

Pod koniec XX wieku nastąpiło wiele zmian w otoczeniu przedsiębiorstw, do których zalicza się niezwykle silną presję konkurencyjną na przedsiębiorstwo i związaną z nią nietrwałość przewagi konkurencyjnej. Współczesna konkurencja polega na przeciwstawieniu tradycyjnego sposobu myślenia współczesnemu, co implikuje przyjęcie modelu przedsiębiorstwa totalnego działającego na rynku globalnym $^{19}$.

Tradycyjne strategie konkurencyjności zakładały wiodącą rolę czynników konkurencyjności na rynku kosztów, jakości, różnicowania ofert oraz intensywnej promocji oraz to, że przedsiębiorstwa nie są skłonne do współpracy, czyli przyjmują postawę konfrontacyjną. Tradycyjne strategie nie mają charakteru przedsiębiorcze$\mathrm{go}^{20}$. Natomiast nowe zasobowe strategie konkurencyjności mają charakter przedsiębiorczy i określają pierwotne źródła przewagi konkurencyjnej przedsiębiorstwa oraz zasady ich rozwijania w długim okresie. Strategie te próbują wyjaśnić, co jest przyczyną konkurencyjnych zdolności innowacyjnych przedsiębiorstwa, wyższej jakości produkcji, niższych kosztów czy konkurencyjnej strategii marketingowej.

${ }_{18}$ Strategie konkurencji w poszczególnych rodzajach sektorów M.E. Porter opisuje w swojej książce: Strategia konkurencji. Metody analizy...

${ }_{19}$ Zarzadzanie strategiczne. Koncepcje i metody, red. R. Krupski, AE we Wrocławiu, Wrocław 1999, s. 43.

${ }^{20}$ Z. Pierścionek, Strategie konkurencji..., s. 200. 


\section{Podsumowanie}

W artykule wyjaśniono i porównano pojęcia: koncepcja konkurencyjności przedsiębiorstwa i strategia konkurencji przedsiębiorstwa. Pozwoliło to na wyciągnięcie wniosku, że pojęcia te mają odmienne znaczenie. Koncepcja konkurencyjności jest pojęciem szerszym i zawiera w sobie pojecie strategii konkurencji. Koncepcja konkurencyjności to ogólny sposób osiągania i utrzymania konkurencyjności przez przedsiębiorstwo, natomiast strategia konkurencji jest jednym z elementów koncepcji konkurencyjności - to zestaw celów, które firma chce osiągnąć, i środków, za pomocą których stara się je osiągnąć.

Pod koniec XX wieku zmianie uległy warunki otoczenia konkurencyjnego, a mianowicie wzrósł zasięg konkurencji z lokalnej czy krajowej do międzynarodowej, a nawet do globalnej. Nastąpił wzrost tempa zmian otoczenia rynkowego, technologicznego oraz konkurencyjnego. W warunkach dynamicznych zmian tradycyjne strategie konkurencji okazują się nieskuteczne. Strategie te nie wystarczają, aby przedsiębiorstwo mogło stworzyć i utrzymać przewagę konkurencyjną w długim czasie, co spowodowało konieczność pojawienia się nowych rozwiązań. Zmiany te były przyczyną pojawienia się nowych strategii konkurencji wiążących się z przedsiębiorczością i innowacyjnością, które są uważane za najważniejsze wyznaczniki wzrostu konkurencyjności przedsiębiorstwa.

\section{Literatura}

D'Aveni R.A., Hypercompetitive Rivalries, The Free Press, New York 1995.

Fryzeł B., Kultura a konkurencyjność przedsiębiorstwa, Tonik, Toruń 2004.

Gluck W.F., Jauch L.R., Business Policy and Strategic Management, ed. 4, McGraw-Hill, New York 1984.

Janasz K., Janasz W., Kozioł K., Szopik-Depczyńska K., Zarzadzanie strategiczne. Koncepcje. Metody. Strategie, Difin, Warszawa 2010.

Łuczak M., Strategie w działalności przedsiębiorstwa, Wyższa Szkoła Ekonomiczna, Warszawa 2003.

Pierścionek Z., Strategie konkurencji i rozwoju przedsiębiorstwa, Wydawnictwo Naukowe PWN, Warszawa 2007.

Pierścionek Z., Strategie rozwoju firmy, Wydawnictwo Naukowe PWN, Warszawa 1998.

Porter M.E., Competitive Strategy, The Free Press, New York 1980. 
Porter M.E., Competitive Advantage, The Free Press, New York 1985.

Porter M.E., Przewaga konkurencyjna. Osiaganie i utrzymywanie lepszych wyników, Helion, Gliwice 2006.

Porter M.E., Strategia konkurencji. Metody analizy, sektorów i konkurentów, MT Biznes, Warszawa 2006.

Przedsiębiorczość a strategie konkurencji, red. T. Tkaczyk, SGH, Warszawa 2000.

Reitsperger W., Daniel S., Tallman S., Chrsmar W., Produkt Quality and Cost Leadership: Compatible Strategies?, „Management International Reviev” 1993, Special Issue No. 1.

Romanowska M., Strategie rozwoju i konkurencji, CIM, Warszawa 1998.

Romanowska M., Zarządzanie strategiczne firma, CIM, Warszawa 1995.

Strategie konkurencji $w$ handlu detalicznym $w$ warunkach globalizacji rynku, red. M. Sławińska, Wydawnictwo Akademii Ekonomicznej w Poznaniu, Poznań 2005.

Szymański W., Przedsiębiorstwo, rynek, konkurencja, SGH, Warszawa 1995.

Uwarunkowania i sposoby wzrostu konkurencyjności przedsiębiorstw, red. M. Białasiewicz, Economicus, Szczecin 2009.

Wright P., A Refinement of Porter's Strategies, „Strategic Management Journal” 1987, Vol. 8. Zarzadzanie strategiczne. Koncepcje $i$ metody, red. R. Krupski, Akademia Ekonomiczna we Wrocławiu, Wrocław 1999.

Zarządzanie strategiczne. Systemowa koncepcja biznesu, red. M. Moszkowicz, PWE, Warszawa 2005.

\title{
APPLICATION OF TRADITIONAL STRATEGIES OF COMPETITIVENESS BY PRESENT-DAY BUSINESSES
}

\begin{abstract}
The article explains and contrasts two ideas: "the concept of competitiveness of a business" and "a strategy of business competition". It tries to solve a dilemma when to use one of the concepts. It discusses selected traditional competitive strategies of businesses. It designates the possibility of application in new conditions of competitive environment.

Translanted by Jolanta Lubomska-Kalisz

Keywords: concepts of competitiveness, strategies of competition, enterprise, competitiveness of businesses
\end{abstract}

JEL code: L26 